\title{
HUBUNGAN INTENSI DENGAN PERILAKU PERAWAT DALAM PENDOKUMENTASIAN ASUHAN KEPERAWATAN DI INSTALASI GAWAT DARURAT
}

\author{
Ardhiles Wahyu Kurniawan \\ Prodi Keperawatan Poltekkes RS dr Soepraoen Malang \\ JI. S. Supriyadi 22 Malang \\ Email : ardhi17wk@gmail.com
}

\begin{abstract}
The complex IGD work environment will affect the quality of care, health care, including inaccurate or incomplete documentation. Incomplete nursing documentation indicates that the nursing care process is not working properly and continuously. Intentionin documenting can predict the appearance of person behavior including the behavior of nurses, especially in documenting nursing care. The purpose of this study was to analyze correlation intention with nurse behavior in documenting nursing care in Emergency Installation. The research design used correlational analysis with cross sectional approach. The sample in this research is part of nurse of executing at IGD Rumkit $T K$ II dr Soepraoen, IGD RS Panti Waluya Sawahan and IGD RS Islam Malang. The sample of 45 nurses IGD and 341 documents were selected according to inclusion and exclusion criteria. The result of statistical analysis of gamma that there is a significant correlation between intention and nursing documentation behavior evidenced by value of $p=0,000$, positive correlation direction and strong correlation value is proved by $r=0,739$. Hospital and nurse IGD is expected to develop a good intention then formed good nursing documenting behavior as well
\end{abstract}

Keywords : Nurse IGD, Intention, Nursing Documentation.

Abstrak: Lingkungan kerja IGD yang kompleks akan mempengaruhi kualitas perawatan, pelayanan kesehatan, termasuk dokumentasi yang dilakukan tidak tepat atau tidak lengkap. Dokumentasi keperawatan yang tidak lengkap menunjukkan proses asuhan keperawatan tidak berjalan dengan baik dan berkesinambungan. Intensi dalam pendokumentasian dapat memprediksi munculnya perilaku seseorang termasuk perilaku perawat khususnya dalam pendokumentasian asuhan keperawatan. Tujuan penelitian ini untuk menganalis hubungan intensi dengan perilaku perawat dalam pendokumentasian asuhan keperawatan di Instalasi Gawat Darurat. Desain penelitian menggunakan analysis correlationaldengan pendekatan cross sectional. Sampel dalam penelitian ini adalah sebagian perawat pelaksana di IGD Rumkit TK II dr Soepraoen, IGD RS Panti Waluya Sawahan Malang dan IGD RS Islam Malang. Sampel berjumlah 45 perawat IGD dan 341 dokumen dipilih sesuai dengan kriteria inklusi dan ekslusi. Hasil analisis statistik uji gammamenunjukkan terdapat hubungan signifikan antara intensi dengan perilaku pendokumentasian keperawatan dibuktikan dengan nilai $p=0,000$, arah korelasi positif, dan nilai korelasi kuat dibuktikan dengan nilai $r$ $=0,739$. Rumah Sakit dan perawat IGD diharapkan mengembangkan intensi yang baik sehingga diharapkan terbentuk perilaku pendokumentasian keperawatan yang baik pula.

Kata Kunci : Perawat IGD, Intensi, Dokumentasi Keperawatan.

\section{PENDAHULUAN}

Pelayanan keperawatan gawat darurat menjadi salah satu area yang paling sensitif diantara pelayanan keperawatan yang lain karena adanya faktor urgency (keadaan mendesak) dan crowding (keadaan yang penuh sesak dan ramai) (Aacharyaet al, 2011). Beban kerja, keramaian, bencana, kematian dan kondisi pasien yang kritis mengakibatkan lingkungan kerja IGD lebih kompleks dan penuh stress (Healy \& Tyrell, 2011). Lingkungan kerja IGD yang kompleks akan mempengaruhi kualitas perawatan, pelayanan kesehatan, keselamatan pasien, termasuk dokumentasi yang dilakukan tidak tepat atau tidak lengkap (Hoot \& Aronsky, 2008; Powell et al, 2012). Kualitas dokumentasi keperawatan di Indonesia masih rendah. Terlihat dari penelitian yang dilakukan Sabila (2009) dari 300 sampel rekam medik dokumentasi keperawatan $69,3 \%$ berada dalam kategori tidak lengkap. Purwanti (2012) kelengkapan dokumentasi keperawatan hanya $63 \%$ yang terdiri dari kelengkapan pengkajian hanya $53 \%$, diagnosa dan perencanaan keperawatan $61 \%$, dan implementasi dan evaluasi $75 \%$. Fuchtbauer et al, 2013 melakukan riset untuk mengetahui proporsi waktu yang dihabiskan oleh perawat dalam melakukan perawatan pada pasien di Instalasi Gawat Darurat. Penelitian tersebut didapatkan hasil bahwa 
perawat menghabiskan $25 \%$ waktu mereka untuk melakukan kontak atau tindakan pada pasien secara langsung, $5,8 \%$ waktu dihabiskan untuk melakukan perawatan pada pasien secara tidak langsung, 24\% waktu dihabiskan untuk melakukan komunikasi pada staf lainnya, $31 \%$ untuk melakukan dokumentasi terhadap segala tindakan yang dilakukan kepada pasien, dan $6 \%$ dilakukan untuk melakukan transportasi pasien.

Gambaran kelengkapan dokumentasi pada analisa rekam medik dalam studi aplikasi di Instalasi Gawat Darurat 12-30 Desember 2016 didapatkan hasil di Rumkit TK II dr Soepraoen 10-60 \% data pengkajian berupa (waktu masuk, identitas pasien, primary survey, secondary survey dan keadaan umum) diisi kurang lengkap, keterkaitan diagnosa dan rencana keperawatan didapatkan $64 \%$ tidak sesuai. Di RS Islam Unisma Malang 20-40 \% data pengkajian keperawatan tidak diisi. ada $80 \%$ diagnosa keperawatan tidak diisi, serta $47-71 \%$ rencana tindakan keperawatan tidak diisi.

Menurut hasil wawancara beberapa perawat pelaksana IGD Rumkit TK II dr Soepraoen bahwa mereka tidak kesulitan dalam mengisi lembar dokumentasi dan menurut mereka lembar dokumentasi di IGD sudah praktis dan lengkap. Menurut perawat IGD RS Islam Malang form pengkajian di IGD antara medis dan perawat perlu dijadikan 1 form pengkajian terintegrasi sehingga lebih praktis. Perawat juga merasa perlu mendapatkan sosialisasi dan superfisi secara kontinyu terkait kelengkapan dokumen di IGD.

Dokumentasi keperawatan merupakan bukti pencatatan dan pelaporan perawat yang berguna untuk kepentingan klien, perawat dan tim kesehatan dalam memberikan pelayanan kesehatan dengan dasar komunikasi yang akurat dan lengkap secara tertulis (Setiadi, 2014). Pribadi (2009), dokumentasi keperawatan yang tidak lengkap menunjukkan proses asuhan keperawatan tidak berjalan baik dan berkesinambungan, tidak terjalin komunikasi yang baik antar perawat dan dengan petugas kesehatan lain karena tidak ada komunikasi tertulis secara jelas. Berdasarkan hasil penelitian Diyanto (2007), Faktor penghambat pada pendokumentasian keperawatan diantaranya beban kerja yang tinggi, lembar isian dokumen terlalu panjang dan mendampingi visite dokter. Bijani et al (2016), faktor mempengaruhi ketidak lengkapan dokumentasi terdiri dari faktor perawat (jumlah perawat kurang, tidak cukup waktu, kelelahan), faktor lingkungan kerja (jumlah pasien banyak, bekerja diarea yang padat), faktor manajemen (tidak ada monitoring, kurang disiplin, dan kurangnya dorongan). Berbagai riset lebih banyak melihat dari faktor eksternal perawat, sedangkan faktor dari dalam yaitu niat yang membentuk perilaku perawat belum banyak dilakukan.

Eccles et al. (2007) menyimpulkan bahwa intense / niat adalah ukuran baku terbentuknya perilaku pada petugas kesehatan (yaitu, dokter, perawat, apoteker, tenaga kesehatan lainnya). Mereka tidak mengukur kekuatan hubungan antara niat dan perilaku di kalangan profesional kesehatan, tetapi berdasarkan penelaahan atas sepuluh studi prospektif, mereka menyimpulkan bahwa hubungan ini sama besarnya dengan yang dilaporkan untuk populasi non tenaga kesehatan.

Intensi merupakan faktor terdekat yang dapat memprediksi munculnya perilaku perawat dalam pendokumentasian keperawatan (Fishbein \& Ajzen, 2010). Penelitian Martini (2007), sikap memiliki korelasi terhadap dokumentasi keperawatan. Rahim A (2009) dan Nelfiyanti (2009), motivasi intrinsik dan persepsi terhadap pekerjaan berperan terhadap kelengkapan pengisian dokumentasi.

Berdasarkan latar belakang diatas perilaku perawat berperan penting bagi baik atau tidaknya dokumentasi khususnya di Instalasi Gawat Darurat. Peneliti tertarik melakukan penelitian tentang hubungan intensi dengan perilaku perawat dalam pendokumentasian asuhan keperawatan di Instalasi Gawat Darurat.

\section{METODE}

Penelitian ini menggunakan desain analysis correlational dengan pendekatan cross sectional. Penelitian ini dilakukan di 3 RS yaitu Rumkit TK II dr Soepraoen (21 perawat), RS Panti Waluya Sawahan Malang (15 perawat) dan RS Islam Malang (15 perawat). Populasi perawat IGD dari ketiga RS tersebut sebanyak 51. Pengambilan sampel dengan purposive sampling didapatkan 45 perawat pelaksana IGD. Lembar dokumentasi keperawatan IGD yang dilakukan observasi sejumlah 341 dokumen selama 10 hari kunjungan. Pengambilan data dalam penelitian ini dilaksanakan pada 18 Mei 2017 sampai dengan 12 Juni 2017. Instrumen penelitian menggunakan kuesioner intensi dan lembar observasi. Instrumen kuisioner diambil dari Nursalam, 2013 yang sudah disesuaikan dengan TPB, selanjutnya dilakukan uji validitas dan reliabilitas. Lembar dokumen yang diiobservasi menggunakan dokumen masingmasing IGD yang sudah resmi dipakai rumah sakit. Peneliti menilai baik/kurang berdasarkan kelengkapan pengisian sesuai dokumen tiap rumah sakit. 
Analisis univariat data kategorik yang terdiri dari jenis kelamin, tingkat Pendidikan, intensi dan perilaku perawat dilakukan analisa dengan menghitung distribusi frekuensi masing-masing kelompok. Analisis bivariat menggunakan uji pearson untuk mengetahui hubungan intensi dengan perilaku perawat dalam pendokumentasian di IGD.

\section{HASIL PENELITIAN}

\section{Karakteristik Responden}

Data Jenis Kelamin, Usia dan Tingkat Pendidikan Responden menginformasikan bahwa sebagian besar jenis kelamin responden adalah perempuan yaitu 28 orang $(62,2 \%)$, hampir semua tingkat pendidikan responden adalah D3/D4 keperawatan yaitu 41 orang $(91,1 \%)$, sebagian besar usia responden $21-30$ tahun yaitu 25 orang $(55,6 \%)$.

\author{
Intensi Dalam Pendokumentasian Asuhan \\ Keperawatan \\ Intensi Perawat Dalam Perilaku
} Pendokumentasian Asuhan Keperawatan di IGD sebagian besar dalam kategori cukup yaitu 34 responden $(76 \%)$ dan sebagihan kecil baik (24\%). Uraian Intensi Perawat Dalam Perilaku Pendokumentasian Asuhan Keperawatan di IGD menunjukan sebagian besar komponen intensi perawat terhadap perilaku pendokumentasian asuhan keperawatan di IGD dengan kategori baik dengan skor tertinggi yaitu dokumentasi secara jelas dan ringkas (skor 152), selanjutnya dokumentasi sesuai masalah keperawatan (skor 148), dokumentasi menggambarkan tindakan mandiri, kolaborasi (skor 147), dokumentasi sesuai diagnosis, prioritas, terinci dan jelas (skor 136) dan yang terendah adalah dokumentasi lengkap sesuai format.

Tabel 1. Uraian Perilaku Pendokumentasian

\begin{tabular}{cccc}
\hline \multirow{2}{*}{$\begin{array}{c}\text { Perilaku Pendokumentasian } \\
\text { Keperawatan di IGD }\end{array}$} & \multirow{2}{c}{ Kategori } & \multicolumn{2}{c}{$\begin{array}{c}\text { Jumlah Dokumentasi Rekam Medik } \\
\text { IGD }\end{array}$} \\
\cline { 2 - 4 } & & $\mathrm{F}$ & $\%$ \\
\hline \multirow{2}{*}{ Pengkajian } & Baik & 235 & 68.9 \\
\cline { 2 - 4 } & Cukup & 106 & 31.1 \\
\cline { 2 - 4 } Diagnosis & Baik & 139 & 40.8 \\
\cline { 2 - 4 } & Cukup & 202 & 59.2 \\
\cline { 2 - 4 } Rencana & Baik & 136 & 39.9 \\
\cline { 2 - 4 } & Cukup & 205 & 60.1 \\
\cline { 2 - 4 } Implementasi & Baik & 261 & 76.5 \\
\cline { 2 - 4 } & Cukup & 80 & 23.5 \\
\hline \multirow{2}{*}{ Evaluasi } & Baik & 219 & 64.2 \\
\cline { 2 - 4 } & Cukup & 122 & 35.8 \\
\hline
\end{tabular}

Tabel 1 menginformasikan bahwa uraian perilaku pendokumentasian asuhan keperawatan yang baik didominasi oleh implementasi keperawatan yaitu 261 dokumen (76.5\%), disusul pengkajian keperawatan yaitu 235 dokumen $(68.9 \%)$. Sebaliknya perilaku pendokumentasian asuhan keperawatan yang kurang didominasi oleh rencana keperawatan yaitu 205 dokumen (60.1\%), disusul diagnosa keperawatan yaitu 202 dokumen(59.2\%).

\section{Analisis Bivariat}

Tabel 2 Hasil Uji Statistik Korelasi

\begin{tabular}{|c|c|c|c|c|}
\hline \multicolumn{2}{|c|}{ Hubungan Antar Variabel } & $\mathrm{p}$ & $r$ & Keterangan \\
\hline Intensi & $\begin{array}{c}\text { Perilaku } \\
\text { Pendokumentasian }\end{array}$ & 0,000 & 0,739 & $\begin{array}{c}\text { Signifikan } \\
\text { Korelasi kuat. } \\
\text { (Uji gamma) }\end{array}$ \\
\hline
\end{tabular}


Berdasarkan Tabel 2 hasil uji statitistik dijelaskan bahwa terdapat hubungan signifikan antara intensi dengan perilaku pendokumentasian asuhan keperawatan. Dibuktikan dengan nilai $p=0,000<0,05$. Hasil penelitian menunjukkan tingkat korelasi intensi dengan perilaku pendokumentasian asuhan keperawatan adalah kuat. Dibuktikan dengan nilai $r=0,739$ (0,6-0,8).

\section{PEMBAHASAN}

\section{Hubungan Antara Intensi Dengan Perilaku Pendokumentasian Asuhan Keperawatan}

\begin{abstract}
Hasil penelitian menunjukkan intensi perawat pada perilaku pendokumentasian asuhan keperawatan di IGD didapatkan sebagian besar dengan kategori cukup yaitu 34 perawat $(76.0 \%)$. Pada hasil uraian intensi perawat dengan perilaku pendokumentasian asuhan keperawatan di IGD sebagian besar dengan kategori baik dengan skor tertinggi yaitu dokumentasi secara jelas dan ringkas, selanjutnya dokumentasi sesuai masalah keperawatan.
\end{abstract}

Dokumentasi keperawatan IGD yang berkualitas dibuat berdasarkan prioritas, terinci dan jelas serta ringkas. Prioritas artinya mendahulukan pada masalah pasien yang mengancam nyawa atau tingkat kegawatan berat, selanjutnya turun ke masalah yang tidak mengancam nyawa. Pendokumentasian secara terinci dan jelas menggambarkan akurasi data sesuai masalah pasien. Ringkas menunjukkan efisiensi dan efektifitas dokumentasi IGD tanpa mengurangi kualitas dokumentasi itu sendiri.

Proses dokumentasi keperawatan dalam bidang gawat darurat memiliki fokus berbeda pada tahap pengkajian karena terkait kondisi akut pasien atau kegawatdaruratan yang mengancam nyawa (lyer, 2004; Asmadi, 2008). Seluruh data yang diperlukan untuk mengidentifikasi masalah keperawatan klien dicatat dengan terperinci. Data yang terkumpul harus lengkap, guna membantu mengatasi masalah klien yang adekuat, akurat dan nyata (Potter \& Perry, 2011). Kuehl (2005), menambahkan bahwa dokumentasi yang tepat, mudah dibaca dan lengkap akan menjamin kualitas perawatan dari potensial gugatan malpraktik.

Perawat IGD menyadari dokumentasi keperawatan yang dibuat harus menggambarkan masalah yang dialami pasien, karena asuhan keperawatan yang diberikan bertujuan mengatasi masalah pasien. Oleh karena itu akurasi atau ketepatan data pada saat pengkajian sangat diperlukan agar sesuai dengan masalah pasien yang sebenarnya. Hasil penelitian sesuai dengan pernyataan Eeden (2009) bahwa dokumentasi keperawatan dalam praktik keperawatan akan membantu memecahkan masalah dan memenuhi kebutuhan perawatan kesehatan pasien.
Tarwato \& Wartonah (2006), proses dokumentasi digunakan untuk membantu melaksanakan praktik keperawatan secara sistematis dan memecahkan masalah keperawatan.

Hasil penelitian menunjukkan perilaku pendokumentasian keperawatan di IGD sebagian besar kategori cukup disebabkan kekurangan pada bagian rencana keperawatan dan diagnosa keperawatan. Perilaku pendokumentasian di IGD lebih banyak berfokus di pengkajian, implementasi dan evaluasi keperawatan. Situasi pasien IGD yang mengancam dan kritis menyebabkan data yang diperoleh dari pengkajian langsung diimplementasikan ke pasien sambil diamati hasil dari tindakan tersebut dalam bentuk evaluasi. Sesuai dengan pernyataan lyer (2004); dan Asmadi (2008), penerapan proses keperawatan di IGD juga berbeda sesuai karakteristiknya, seperti tahap pengkajian selesai dilakukan lalu akan langsung ditindaklanjuti ke tahap implementasi untuk menyelamatkan kondisi yang mengancam nyawa.

Pada kegiatan penelitian didapatkan dua IGD RS tidak menggunakan format cek list tapi menggunakan isian pada bagian diagnosa dan rencana keperawatannya. Hasil observasi peneliti bentuk isian pada diagnosa dan rencana keperawatan ini menyebabkan sering tidak diisi daripada bentuk cek list. Bentuk isian diagnosa dan rencana keperawatan di IGD memerlukan waktu menulis lebih lama dan membutuhkan pengetahuan perawat yang lebih baik. Keterkaitan diagnosa dan rencana keperawatan sangat erat, biasanya bila diagnosa keperawatan tidak dibuat maka rencana keperawatan juga tidak dibuat.

Hasil penelitian Paans et al (2010) bahwa penulisan formulasi diagnosis keperawatan relatif jarang dilakukan dan tidak terdokumentasi dengan baik. Penelitian Adeyemi dan Olagon (2013) bahwa faktor pengetahuan perawat memilik pengaruh lebih besar dari faktor lainya dalam aplikasi proses keperawatan sehingga perawat tidak dapat merumuskan sesuai formulasi diagnosis keperawatan. Eeden (2009); Paans et al (2010) menyatakan bahwa diagnosis akan memberikan dasar dalam menyusun rencana keperawatan untuk mencapai akhir yang diinginkan untuk pasien.

Hasil menunjukkan bahwa intensi perawat dalam pendokumentasian asuhan keperawatan memiliki hubungan signifikan dengan perilaku perawat dalam 
pendokumentasian asuhan keperawatan. Perilaku pendokumentasian asuhan keperawatan yang baik dipengaruhi oleh intensi yang baik.

Faktor intensi perilaku merupakan inti dari perilaku terencana, namun penyebab intensi tidak hanya dua (sikap terhadap perilaku pendokumentasian asuhan keperawatan dan norma subyektif) melainkan tiga dengan diikutsertakan aspek kontrol perilaku (Perceived Behavional Control). Ketiga komponen ini berinteraksi dan menjadi determinan bagi intensi yang pada gilirannya akan menentukan apakah perilaku yang bersangkutan dalam hal ini perilaku pendokumentasin asuhan keperawatan akan dilakukan atau tidak (Azwar,2010)

Ajzen menyatakan bahwa niat seseorang melakukan perilaku akan menentukan dilakukan atau tidak dilakukan perilaku tersebut (Ajzen, Albarracin, \& Hornik, 2010). Intensi merupakan faktor motivasional yang memiliki pengaruh pada perilaku, sehingga orang dapat mengharapkan orang lain berbuat sesuatu berdasarkan intensinya. Pada umumnya, intensi memiliki kolerasi yang tinggi dengan perilaku, oleh karena itu dapat digunakan untuk meramalkan perilaku. Intensi diukur dengan sebuah prosedur yang menempatkan subyek di dimensi probabilitas subyektif yang melibatkan suatu hubungan antara dirinya dengan tindakkan (Fishbein \& Ajzen, 2010). Intensi juga merupakan faktor penentu apakah perilaku yang bersangkutan dalam hal ini perilaku pendokumentasian asuhan keperawatan akan dilakukan atau tidak (Azwar, 2010).

Berdasarkan hasil penelitian menunjukkan bahwa intensi perawat dalam pendokumentasian asuhan keperawatan memiliki hubungan signifikan terhadap perilaku perawat dalam pendokumentasian asuhan keperawatan. Hubungan ini dapat diprediksi bahwa intensi sebagai faktor motivasional yang menentukan seorang melakukan pendokumentasian asuhan keperawatan dan mengindifikasikan seberapa kuat keyakinan seseorang akan menerapkan suatu perilaku dan seberapa besar usaha yang akan digunakan untuk melakukan perilaku tersebut.

\section{DAFTAR PUSTAKA}

Aacharya et al, 2011. Emergency Department Triage: An Ethical Analysis. BMC Emergency Medicine, 11(16): 1-13

Ajzen, I., Albarracin, D., dan Hornik, R. 2010. Prediction and Change of Health Behavior. Applying the Reasoned Action Research. LEA Publisher. New Jersey. $\begin{array}{ccc}\text { Intensi } & \begin{array}{c}\text { pendokumentasian } \\ \text { menghang }\end{array} \\ \text { kurang } & \text { perilaku }\end{array}$ pendokumentasian yang kurang, sehingga pendokumentasian yang tidak lengkap atau kosong mulai dari pengkajian, diagnosis keperawatan, rencana, implementasi dan evaluasi. Intensi yang baik menghasilkan perilaku pendokumentasian yang baik, karena intensi yang baik dapat menjadi faktor motivasional yang memiliki pengaruh pada perilaku.

\section{KESIMPULAN}

Intensi berhubungan dengan perilaku perawat dalam pendokumentasian asuhan keperawatan di IGD.

\section{SARAN}

\section{Rumah Sakit}

Untuk memperbaiki perilaku pendokumentasian asuhan keperawatan di IGD perlu dilakukan dorongan intensi perawatyang didukung dengan peraturan RS dan SOP yang jelas tentang pendokumentasian asuhan keperawatan. Sosialisasi berkala kepada perawat pelaksana tentang pendokumentasian khususnya menyusun diagnosa dan rencana keperawatan, sebagai upgrade pengetahuan dan terjadi persamaan persepsi perawat dalam pendokumentasian keperawatan.

\section{Perawat}

Meningkatkan niat yang baik dalam pendokumentasikan asuhan keperawatan, sehingga akan terbentuk perilaku yang baik pada pendokumentasian asuhan keperawatan.

\section{Penelitian Lanjut}

Observasi dalam perilaku pendokumentasian dapat dilakukan secara langsung pada saat perawat melakukan pendokumentasian asuhan keperawatan dalam rentang waktu penelitian yang lebih lama.

Asmadi, 2008. Konsep Dasar Keperawatan. EGC. Jakarta

Bijani, M., Sadeghzadeh, M., Khani, J.A., dan Kashfi, S.H. 2016. Factors Influencing Poor Nursing Documentation from The Perspective of Nursing Staff. International Journal of Medical Research \& Health Sciences, 5(11): 717-718. 
Diyanto, Y 2007, Analisis Faktor-Faktor Pelaksanaan Dokumentasi Asuhan Keperawatan di RSUD Tugurejo Semarang, Tesis, Menyediakan format.Universitas Diponegoro, Semarang

Eeden, I.E. 2009. Development of A Nursing Record Tool for Critically III Injuried Patients in An Accident and Emergency (A\&E) Units. Dissertation. University of Pretoria.

Fishbein, M \& Ajzen, I, 2010, Predicting and Changing Behavior: The Reasoned Action Approach, Psychology Press, New York.

Healy, S., dan Tyrrell, M. 2011. Stress in Emergency Departments: Experiences of Nurses and Doctors. Emergency Nurse, 19(4): 31-36

Hoot, N.R., dan Aronsky, D. 2008. Sistematic Review of Emergency Department Crowding: Causes, Effects and Solutions. Annals of Emergency Medicine, 52(2): 126-136.

lyer, P.W., dan Camp, N.H. 2004. Dokumentasi Keperawatan: Suatu Pendekatan Proses Keperawatan. EGC. Jakarta.

Kuehl, A. 2005. Documentation Crisis in The Emergency Department. Dateline, 3(1): 1-5

Martini 2007, Hubungan Karakteristik Perawat, Sikap, Beban Kerja, Ketersediaan Fasilitas Dengan Pendokumentasian Asuhan Keperawatan di Rawat Inap RSUD Kota Salatiga, Tesis, Universitas Diponegoro, Semarang

Nelfiyanti, 2009, Pengaruh Pengetahuan dan Motivasi Perawat Terhadap Kelengkapan Pengisian Dokumentasi Asuhan Keperawatan pada Rekam Medis di Ruang Rawat Inap RSH Medan, Tesis, Universitas Sumatera Utara, Medan.
Paans, W., Sermeus, W., Nieweg, R.M.B dan Van Der Schans, G.P. 2010. Prevalence of accurate nursing documentation in patient records. Journal of Advance Nursing, 66(11):2481-2489

Potter, P, \& Perry , 2011, Basic nursing, Ed. 7th. Mosby Elsevier, Canada

Pribadi, A. 2009. Analisis Pengaruh Faktor Pengetahuan, Motivasi, Dan Persepsi Perawat Tentang Supervisi Kepala Ruang Terhadap Pelaksanaan Dokumentasi Keperawatan Di Ruang Rawat Inap RSUD Kelet, Jepara. Tesis. Universitas Diponegoro. Semarang.

Purwanti. (2012). Kelengkapan Dokumentasi Asuhan Keperawatan dan Karakteristiknya Pada Pasien Rawat Inap Dewasa Nn Kebidanan di Rumah Sakit Haji Jakarta. Tesis FKM UI.

Rahim, A ,2009, Pengaruh Karakteristik Individu, Faktor Psikologis dan Organisasi Terhadap Pendokumentasian Asuhan Keperawatan pada Instalasi Rawat Inap RSUD Dr. Zainoel Abidin Nanggroe Aceh Darussalam, Tesis, Universitas Sumatera Utara, Medan.

Sabila. (2009) Evaluasi Kelengkapan Pengisian Format Pengkajian Keperawatan Narasi Dan Format Pengkajian Keperawatan Checklist Terintegrasi Di RSUD Sleman Yogyakarta. Skripsi .UGM.

Setiadi, 2012. Konsep dan Penulisan Dokumentasi Asuhan Keperawatan: Teori dan Praktik. Graha IImu. Jakarta.

Tarwoto dan Wartonah, 2006. Kebutuhan Dasar Manusia dan Proses Keperawatan. Ed.3. Salemba Medika. Jakarta. 